\title{
Infeksi parasit gastrointestinal pada kambing di Kupang
}

\author{
Aji Winarso \\ Fakultas Kedokteran Hewan, Universitas Nusa Cendana, Nusa Tenggara Timur
}

ABSTRAK: Produktivitas ternak kambing di lahan kering Nusa Tenggara Timur yang dipelihara secara tradisional semiintensif sangat dirugikan oleh parasit. Studi kasus selama bulan Juli 2016 pada 5 peternakan rakyat ini mendeskripsikan pola pemeliharaan ternak kambing di Kupang yang dikaitkan dengan risiko infeksi/infestasi parasit. Kambing sebanyak 20 ekor dari 5 peternakan kambing di Kota Kupang (Kelurahan Manutapen, Kelurahan Lasiana) dan di Kabupaten Kupang (Desa Pariti dan Desa Oenesu) terdiri dari berbagai umur diambil sampel feses untuk pemeriksaan parasit kualitatif dengan metode pengapungan sederhana. Observasi dilakukan terhadap perkandangan dan padang penggembalaan. Wawancara terstruktur pada pemilik peternakan untuk mengetahui tata kelola peternakan. Hasil kajian menunjukkan semua ternak terinfeksi parasit saluran pencernaan berupa cacing kelompok strongil, cacing Strongyloides, cacing Trichuris dan protozoa Eimeria spp. Sistim peternakan kambing yang dikelola secara tradisional semi-intensif sebagai usaha sampingan dimana ternak dilepas saat cuaca cerah, kandang alas tanah tanpa pemisahan umur, dan kotoran jarang dibersihkan mendukung siklus hidup parasit.

Kata kunci:

kambing kacang, lahan kering, helminthiasis, koksidiosis

\section{- PENDAHULUAN}

Ternak kambing merupakan salah satu alternatif bagi pemenuhan kebutuhan protein hewani karena memiliki siklus reproduksi lebih cepat dibandingkan sapi dan kerbau. Penyakit utama ternak kambing adalah penyakit parasiter saluran pencernaan. Penyakit parasiter dapat menurunkan performans ternak dan kerugian ekonomi bagi peternak (Pfukenyi \& Mukaratirwa 2013). Infeksi tunggal atau campuran oleh koksidia dan cacing nematoda sangat berdampak pada produksi, bahkan kematian ternak muda (Bowman 2009).

Pengendalian parasit tidak dapat dilakukan hanya dengan antiparasit, karena menjadi beban biaya berlebih dan meningkatkan risiko resistensi. Program pengendalian parasit harus berdasarkan data epidemiologis dan diaplikasikan dalam tata kelola peternakan. Studi kasus ini memaparkan tata kelola peternakan kambing skala kecil di Kota dan Kabupaten Kupang, Nusa Tenggara Timur serta hubungannya dengan infeksi parasit saluran pencernaan.

\section{- BAHAN DAN METODE}

Studi dilakukan pada 5 peternakan kambing skala kecil di Kabupaten Kupang (Kelurahan Manutapen dan Lasiana) dan Kota Kupang (Desa Pariti dan Oenesu), Nusa Tenggara Timur pada Juli 2016. Kambing sebanyak 20 ekor dari berbagai kelompok umur diambil feses untuk pemeriksaan parasit secara kualitatif metode pengapungan sederhana. Observasi dilakukan pada kondisi lingkungan perkandangan dan padang penggembalaan. Wawancara terstruktur kepada peternak untuk mengetahui tata kelola peternakan.

\section{- HASIL DAN PEMBAHASAN}

Peternakan kambing skala kecil di Pulau Timor merupakan usaha sampingan dan dikelola dengan sistem semi-intensif. Kambing dikandangkan pada malam hari dan dilepas pada pagi hingga sore hari tanpa penggembala. Ternak kambing dilepas setiap hari pada musim kemarau, sedangkan pada musim penghujan dilepas apabila hari cerah. Ternak diberi pakan hijauan ketika musim hujan. Peternak memberi kalung batang kayu untuk mencegah kambing masuk ke areal perkebunan tanaman pangan atau persawahan orang lain (Gambar 1). Perangkat ini membantu peternak terhindar dari denda sesuai peraturan desa apabila ternak masuk dan merusak perkebunan orang lain.

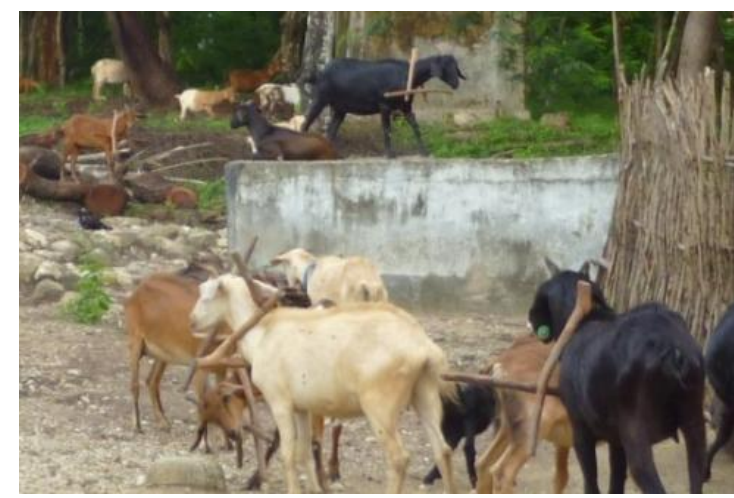

Gambar 1. Kambing dilepas untuk mencari makan dengan kalung dari batang kayu pada leher.
Diterima: 08-02-2018 | Direvisi: 19-02-2018 | Disetujui: 12-03-2018 (C) 2018 CC-BY-SA. Ini adalah artikel Open Access yang didistribusikan berdasarkan ketentuan dari Creative Commons Attribution ShareAlike 4.0 International License (https://creativecommons.org/licenses/by-sa/4.0/). 
Sebagian besar kandang berbahan kayu dengan atap daun lontar (Gambar 2a). Satu dari lima kandang beratap seng (Gambar 2b). Alas kandang berupa tanah, satu kandang beralaskan papan kayu dan satu lainnya beralaskan batang kayu sisa hijauan lamtoro dan gamal (Gambar 2c). Dinding kandang dari kayu dibuat tidak rapat. Peternak tidak memisahkan umur ternak dalam kandang (Gambar 2d). Anak kambing yang telah berumur lebih dari 1 bulan sudah diumbar dalam kelompok ternak gembala.

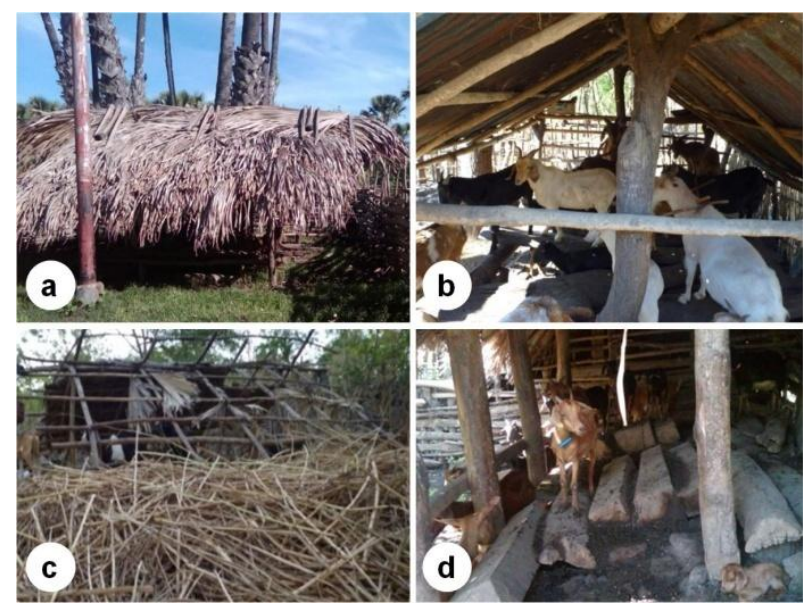

Gambar 2. Sistim kandang: (a) Kandang kayu dengan atap daun lontar dan beralaskan tanah, (b) kandang kayu dengan atap seng, (c) alas kandang sisa pakan hijauan, dan (d) kandang tanpa pemisahan berdasarkan kelompok umur.

Hasil pemeriksaan sampel feces dijumpai parasit saluran pencernaan cacing kelompok strongil, cacing Strongyloides, cacing Trichuris dan protozoa Eimeria spp (Gambar 3a-f). Tidak ditemukan parasit cestoda. Cacing strongil yang mungkin ditemukan pada kambing yaitu Haemonchus, Trichostrongylus (Nabi et al. 2014), Oesophagostomum, Bunostomum (Mondal et al. 2000), Cooperia, dan Mecistocirrus (Zajac \& Conboy 2012). Semua ternak telah terinfeksi parasit saluran pencernaan dengan variasi jenis parasit berbeda. Ternak gembala mudah terserang penyakit parasiter. Kontaminasi silang antar kelompok ternak terjadi di padang penggembalaan umum (Winarso et al. 2015). Peternak tidak pernah memberikan anthelmintika atau antiparasit pada kambing. Peternak perlu menyadari parasit dan deworming dilakukan secara terprogram (Tshering \& Dorji 2016). Pengobatan dari parasit penting pada ternak gembala (Stadalienè et al. 2015).

Satu ekor anak kambing positif terinfeksi parasit saluran pencernaan menunjukkan gejala diare berat (Gambar 3g). Ternak muda lebih rentan terserang infeksi parasit. Ternak dewasa berperan sebagai reservoir (Pfukenyi \& Mukaratirwa 2013). Pemisahan ternak muda dari ternak dewasa dapat mengurangi risiko infeksi parasit terhadap ternak muda, apalagi kondisi kandang beralaskan tanah dan jarang dibersihkan dari kotoran ternak.

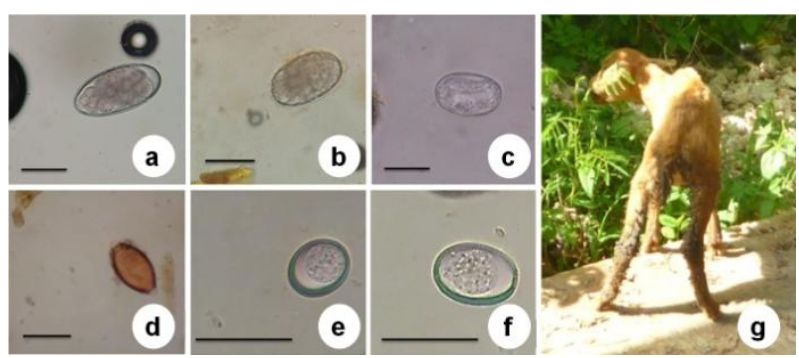

Gambar 3. Telur cacing dan ookista pada feces, bar: $35 \mu \mathrm{m}$ : (a-b) telur nematoda strongyloid, (c) telur Strongyloides (d) telur Trichuris, (e-f) ookista Eimeria. (g) diare pada anak kambing terinfeksi parasit.

\section{SIMPULAN}

Tata laksana peternakan kambing skala kecil di Kupang Nusa Tenggara Timur dengan pola perkandangan semiintensif mendukung siklus hidup parasit saluran pencernaan.

\section{— INFORMASI PENULIS}

\section{Penulis untuk Korespondensi}

*AW: ajiwinarso@staf.undana.ac.id

Laboratorium Parasitologi, Departemen Ilmu Penyakit Hewan dan Kesehatan Masyarakat Veteriner, Fakultas Kedokteran Hewan, Universitas Nusa Cendana, Nusa Tenggara Timur

\section{- TERIMA KASIH}

Terima kasih kepada Prof Wasmen Manalu, Dr. Andriyanto, Dr. Aulia A. Mustika yang telah menjalin kerja sama dengan peternak melalui program Masterplan Percepatan dan Perluasan Pembangunan Ekonomi Indonesia (MP3EI) periode 2013-2014.

\section{- PUSTAKA ACUAN}

Bowman DD. 2009. Georgis' Parasitology for Veterinarians. 9th ed. St. Louis, Missouri: Saunders Elsevier.

Mondal MM, Islam MK, Hur J, Lee JH, Baek BK. 2000. Examination of gastrointestinal helminth in livestock grazing in grassland of Bangladesh. Korean J Parasitol. 38(3):187-90.

Nabi H, Saeed K, Shah SR, Rashid MI, Akbar H, Shehzad W. 2014. Epidemiological study of gastrointestinal nematodes of goats in district Swat, Khyber Pakhtunkhwa, Pakistan. Sci Intl. 26(1):283-86.

Stadalienė I, Höglund J, Petkevičius S. 2015. Seasonal patterns of gastrointestinal nematode infection in goats on two Lithuanian farms. Acta Vet Scand. 57(1):1-16.

Pfukenyi DM, Mukaratirwa S. 2013. A review of the epidemiology and control of gastrointestinal nematode Infections in cattle in Zimbabwe. Onderstepoort Journal of Veterinary Research. 80(1): 1-12.

Tshering G, Dorji N. 2016. Prevalence of gastrointestinal parasites in free range cattle; a case study in Haa district, Bhutan. J Anim Health Prod. 1(4):36-37.

Winarso A, Satrija F, Ridwan Y. 2015. Faktor risiko dan prevalensi infeksi toxocara vitulorum pada sapi potong di kecamatan Kasiman, kabupaten Bojonegoro. JIPI. 20(2):85-90.

Zajac AM, Conboy GA. 2012. Veterinary clinical parasitology, 8th Ed. Oxford: Wiley-Blackwell. 